\title{
Effects of Climate Change on Vegetation in Mediterranean Forests: A review
}

\author{
A.D. Solomou*, N.D. Proutsos, G. Karetsos, K. Tsagari \\ Hellenic Agricultural Organization "DEMETER", Institute of Mediterranean Forest Ecosystems, \\ N. Chlorou 1, Ilisia, 11528, Athens, Greece.
}

\begin{abstract}
A systematic literature review was undertaken to analyze the effects of climate change concerning the forests in the Mediterranean region as it is a climate and a global hot spot of biological diversity and the richest biodiversity region in Europe. Climate change threatens several ecosystems (e.g. forests) with ecological and socioeconomic importance. It is noteworthy that all warming scenarios in the Mediterranean predict an increase of drought and heat events, and a reduction in precipitation within the next hundred years in the Mediterranean basin with important consequences in local vegetation communities. Forests can therefore be used as a tool in developing solutions to the problem of climate change. Nowadays, is considered necessary firstly to continue monitoring and research concerning climate change patterns and impacts on regional scales and secondly to implement management strategies in order to preserve Mediterranean habitats.
\end{abstract}

Keywords-Forest, vegetation, management, climate change, adaptation.

\section{INTRODUCTION}

Mediterranean is considered as global biodiversity hotspot $[1,2]$. Expanding between temperate-rainy (South Europe) and arid regions (Africa), constitutes essentially, a transitional zone, werevarious types of ecosystems and species co-exist, but in a delicate balance [3].

Climate change effects have already begun to be felt throughout the Mediterranean. Prolonged periods of drought, frequent and severe storms, flooding, increased extreme heat events and more mega-fires are a testimony to this change. The rapid and acute changes in climatic conditions within the next 100 years is expected to produce an important impact on the Mediterranean forests [4]. Mediterranean ecosystems are characterized by contrasting plant functional types competing for water [5] andare sensitive to warming and alsotochanges in water availability [6]. They have undergone numerous climatic changes in the past, responding with various ways (tolerance to environmental changes as a result of phenotypic plasticity of certain species, adaptation by changing physiological procedures, exploitation of genotypes, immigrationetc) [7]. Further temperature increase and water availability reduction is expected to cause Mediterranean biodiversity loss in the future [8] and have notable impacts on natural vegetation.

Hence, the aim of the present activated review is to present comprehensive information about the effects of climate change concerning the forestsin the Mediterranean region, which has been identified as "climate change hot spot"[9,10].

\section{METHODOLOGY}

In order to review and consolidate existing research on the climate change effects on Mediterranean Forest vegetation, a literature search was conducted using Scopus, Web of Science and Google scholar. A systematic methodology was implemented in order to ensure that a rigorous and repeatable method was applied to each synthetic of the effects of climatic change on vegetation in Mediterranean Forests. The methodology consisted of two stages: (i) the generation of keywords and (ii) a systematic search [11].

\section{RESULTS}

Environmental conditions play an important role in defining the function and distribution of vegetation, in relation with other factors. Changes in long term environmental conditions that can be collectively coined climate change have significant effects on vegetation community structure, composition and distribution pattern in the future [12].

Mediterranean regions are passing climate regions where it has been presumed that climatic changes may have the greatest impacts. Mediterranean regions are also predicted to have minutely intense feedbacks from the earth to the atmosphere [13].

\section{Climate changes}

Climate constitutes a constantly changing system due to both anthropogenic and natural factors. Recent past records indicate a temperature increaseby about $0.85^{\circ} \mathrm{C}$ globally and about $1.3^{\circ} \mathrm{C}$ in the Mediterranean area compared to the levels of the time period of 1880-1920. Cook et al. (2016) [14] refer in their study that the 1998-2012 period was the driest of the last 500 years.

Future climate patterns foresee a further increase of air temperature.It is noteworthy the fact that the predicted 
future changes in temperature over the next period (20162035) are expected to be in the range of $0.3-0.7^{\circ} \mathrm{C}$ [15] under medium confidence levels.

In the Mediterranean basin, models also predict, increases in temperature and heat stress and reduction in precipitation and water availability [16,17]with increases in extreme heat and precipitation events [18]. Extreme temperature events are provided to become more regularly, intense and longer duration than present [19].Generally, all warming scenarios in the Mediterranean predict worse future conditions compared to the global pattern, with warming to exceed $2^{\circ} \mathrm{C}$ at the end of the century.Drier conditions are also expected to threat the Mediterranean habitats $[9,10,20]$.

\section{Land use changes}

Land use changes in the Mediterranean are significant when studying the effects of climate change. Petit et al. (2001) [21] mentions contradicting changes in the basin with deforestation, abandonment and intense use coexisting. Though, the extensive reductions of forests by intense land use [22], wildfires and grazing are the key factors that shaped todaysMediterranean landscape [23].The changes in climate along with those in land uses (conversion of wildlands to agricultural lands and urban areas) are expected affect negatively ecosystems biodiversity [24,2].

\section{Changesinplant growth}

Warming, increase of drought and heat events and drastic reduction in precipitation is likely within the next hundred years in the Mediterranean basin with important consequences in photosynthesis, growth and survival of local vegetation $[25,26]$.

It has been observed that increasing atmospheric $\mathrm{CO}_{2}$ concentration influence plants photosynthesis, consistently the increases in plant water use efficiency enhancing the photosynthetic capacity and favoring the plant growth [27]. Specifically, rising concentrations of $\mathrm{CO}_{2}$ in the atmosphere increase photosynthesis rates and vary with plant nitrogen status and species [28]. For example, mature Fagussylvatica and Quercuspetratea responded more than Carpinusbetulus, Prunusavium, and Tiliaplatyphyllos in a central European free air experiment enrichment [29]. Tree growth rate might not increase proportionally with increase in photosynthesis because of other limiting factors such as nutrient availability[30,31].

Although experiment enrichment or short - term $\mathrm{CO}_{2}$ increase can lead to higher net primary productivity [32], tree ring analysis in the Mediterranean shows the opposite [33] probably due to limitations in water and nutrients availability $[34,35]$. This is in line, with the recorded tree growth reduction [36], increased growth variability [37] and defoliation in Mediterranean forests the last decades.
The higher atmospheric $\mathrm{CO}_{2}$ concentration (increase from $280 \mathrm{ppm}$ in the pre-industrial age to $400 \mathrm{ppm}$ at present, Kennedy 2015 [38]) is not expected to lead to increase in carbon assimilation by natural vegetation in the Mediterranean, mainly because of the impact of drought to metabolic limitation to photosynthesis [39] and limitations in water availability and nutrients [40, 28]. Thus sclerophyllous vegetation, that dominates the Mediterranean, will not be favored by $\mathrm{CO}_{2}$ changes, while thermophilous species will have to deal with better climatic conditions mainly because of the warmer winters[26].

The Mediterranean species are established to temperature zones where temperature is near its optimum values for photosynthesis [40,41]. An increase in temperature (near or beyond its critical values) combined with low water availability, especially in summer, is expected to lead to photosynthesis decline, reduction in $\mathrm{CO}_{2}$ assimilation and stomatal conductance, cell dehydration and necrosis [42]. Though, there are species tolerant to high temperatures with specific morphological characteristics (small thick or trichom covered leaves, small leaf angles with the shoot, etc.) and adaptation strategies (such as completion of biological stages before the drought ignition, intraspecific variability, phenotypic plasticity, local adaptation, e.tc. (seereviews [26,3]) that allow them to grow and survive to warm environments. An interesting review of the adaptation mechanisms of Mediterranean heat tolerant species to drought was presented by Bussottiet al. (2014) [26], who also mention extensively reported tree dieback events in southern Europe and in Mediterranean regions and suffering of sclerophyllous Mediterranean vegetation due to severe drought events.

\section{Changes in vegetation patterns}

Many studies foresee habitat reduction due to climate change though, with different habitat loss rates [2]. The habitat loss [43] and seed production [44] will be affected by climate change, with direct effects to plant communities. Drought [15] and extreme cold events [46] are also found to affect fauna.

The most sensitive vegetation zones in the Mediterranean are those extended to the southern limits of the Mediterranean basin. Changes in atmospheric $\mathrm{CO}_{2}$ concentration (reaching 600ppm at the end of the century [25], will have severe impacts on plant populations (Lenoir et al. 2008), by affecting plant productivity and water use efficiency [48, 49].

Habitat migration to regions with more favorable climate conditions will also occur as a climate change adaptation strategy of vegetation. Though, many plant species cannot meet the needs of velocity transition requirements in order to establish new plant communities in new areas [50]. Tinner and Lotter (2006) [51] calculated that in order to ac- 
complish a $100 \mathrm{~km}$ migration transition, species will need about 250-1000 years, when climate change occurs much faster (according to A1B scenario mean temperature increase velocity will be $42 \mathrm{~km}$ per 100 years and in many regions will reach 100-1000 km per 100 years, [52]).

The spatial climate change shifts will occur with different regional velocities, higher at lowlands and lower in mountainous regions [52,53]. Also, different immigration rates are expected among species with respect to their reproductive dynamics and dispersion strategy. For example, Clark et al. (2001) [54] found migration rates varying from $300 \mathrm{~m}$ per year for boreal spruce to 0.1-1 m per year for animaldisperse species, when Higgins et al. (2003) [55] estimated much higher rates for specific weeds and shrubs reaching $2186 \mathrm{~m}$ per year. In general, Davis et al. (2005) [56] estimated local adaptation times from decades to century for herbs and 100-1000 years for trees.

Altitudinal upward shifts of vegetation have also occurred during past along with immigration to southern (cooler) areas. Bussottiet al. (2014)[26] states that tree species will follow a migration natural pattern from south to north and from low to high altitudes. Lenoir et al. (2008) [47] found upward shift rates in 171 forest plant species in France of about $29 \mathrm{~m}$ per decade, when warming and elevation lapse rates were much higher (about $75 \mathrm{~m}$ per decade).

The evergreen species are generally slower to adaptation in changing environments [57]. Bussottiet al. (2014) [26] states that these species in the Mediterranean, are not expected to respond to the fast climate change rates by evolutionary adaptation, but probably will survive by migration and that the evergreen tree species, in the future will extend to xeric regions that nowdays are covered by deciduous oaks and mountains, while mountain conifers and temperate deciduous species will be limited to their southern extension ranges.

Reduce in frost injuries of plants [58] and increase in winter photosynthesis [59] are expected due to warmer winters in the Mediterranean, with regard to plant species [60]. In general the sensitive to cold species will be favored over the existing cold-tolerant and this will increase speciescompetition and affect forests structure, population dynamics with possible results the conversion of forests to shrublands[60].

The Mediterranean mountains are considered as extremely vulnerable to climate change $[9,10]$. It is predicted that will undergo warming, precipitation decrease and interannual variability more intense than other mountains [20] with higher species losses [61]. Ruiz-Labourdetteet al. (2013)[62] forecast for the Mediterranean mountains' vegetation that xerphylous vegetation will considerably increase and dominate low mountain areas and perennial sclerophyllous species will also increase, while moderatetolerant to water availability vegetation will notably de- crease. At higher altitudes vegetation will up-shifted, the semiarid forests will expand, the broadleaf forest will reduce and cold gymposperm forest will radically reduce their expansion ranges.

\section{Changes in phenology}

Beyond its impact on vegetation composition and species ranges, climate change affects also species phenology and reproductive process. Phenology is affected both by precipitation and temperature $[63,64]$ and can be considered as a reliable index to track climate change impacts to the species ecology [65].

Changes in phenophases have already being tracked the last few decades [66] with advancement of flowering date and increase in the length of the growing season. Parry et al. (2007) [67] found a rate of spring onset advance by 2.35.2 day per decade, since 1970s. Gordo and Sanz (2010) [68] conducted an extensive research in Spain (29 species from 1500 sites) and found advancement rates of 4.8, 5.9 and 3.2 days per decade in leaf-out, flowering and fruiting, respectively and a rate of 1.2 days per decade delay in leaf abscission since 1970s. Morin et al. (2010) [63] conducted experimental warming and found advancing leaf-out of 813 days both for evergreen and deciduous oaks, while Cleland et al. (2006) [69] found advanced flowering by 2-5 days for annual species though with phenological responses variations among groups to elevated $\mathrm{CO}_{2}$ and $\mathrm{N}$ manipulations.Richardson et al. (2013)[70] consider that climate change will result to further advancement of vegetation's growing period in winter-spring and also earlier onset and longer summer drought period.

Drought also affects phenology especially to species sensitive to water availability such as shrubs [71] or grasses. Peñuelas et al. (2003)[72] addresses rainfall and water availability changes, as important factors leading to significant phenological changes in Mediterranean species of bushes such as Erica multifloraandGlobulariaalypum in Catalonia with subsequent changes in the structure, composition and operation of their communities. Though trees are more tolerant because of the structure of their rooting system that allows to exploit soil water from deeper [73].

\section{Changesin wildfires}

Fires are a key factor in the Mediterranean, with their numbers to have increased the last decades [74] and further increase is expected due to climate warming [75]. Additionally, under future climate change patterns, wildfires are expected to be more aggressive and not easily to manage with current fire-suppressing strategies [76].

The forest fires have significant effect on vegetation dynamics in the Mediterranean which is mainly dominated by non-resilient, to fire, species with low regeneration ability [77]. Increases in fires frequency and/or intensity will 
impose the succession by oaks, shrublands and grasslands [78], with high risk for other native species not to succeed seeders regeneration [79] and the risk to increase the invasion of non-native species [3]. In all cases the wildfires frequency and specifically the length of the period between fire events is crucial. According to Valdecantos (2008) [80] if the period between two consecutive fire incidents is too small, is rather unlikely to achieveproper seedregeneration, with consequences to future post-fire succession and rehabilitation of the ecosystem, especially for exclusively seed-regenerated species such as Pinus sp., Ulexparviflorus, Cistus sp. etc.

\section{Changes in soils}

Soil processes are affected by precipitation [81]. Climate change impacts on vegetation is expected also to affect soils due to both climate change [82] and vegetation changes [83]. These soil changes will again adversely affect vegetation dynamics as already occurred during the Holocene [84]. Johnstone and Chapin (2003) [85] mention that the local expansion of pines against spruce, increased fire incidents and reduced soil carbon.Both changes in soils and vegetation regimes will have impacts in local hydrology and water chemistry e.g. lakes [86]. Important is the effect of soil depth on climate change impacts, mainly because it affects evapotranspiration and runoff dynamics [5].

\section{CONCLUDED REMARKS}

Climate change scenarios predict massive impacts on Mediterranean forests. Though, changes in climate have also occurred in the past and plants managed to adapt to the new established environments through morphological, anatomical, physiological and molecular mechanisms and processes [57]. In the Mediterranean plants adopted survival mechanisms in order to avoid the winter frost or summer drought. Webb (1986) [87] estimates that vegetation adaptation will occur fast enough, so to accomplish equilibrium with climate.

Doblas-Miranda (2016) [3] mentions that different climate change factors, when combined, can alter the effect of others, changing the impacts of global change, especially in the Mediterranean, where many contradicting factors coexist. They also state that "although global change is unavoidable in many cases, change does not necessarily mean catastrophe, but adaptation" and consider as a challenge the conservation of Mediterranean ecosystems.

Under this point of view and in order to meet climate change challenge, it is considered necessary a) to continue monitoring and research concerning climate change patterns and impacts on regional scales and b) to implement management strategies in order to preserve Mediterranean habitats and improve vegetation's adaptation to the new established environments.

\section{REFERENCES}

[1] Myers, N., Mittermeier, R.A., Mittermeier, C.G, da Fonseca, G.A.B. and Kent, J. (2000). Biodiversity hotspots for conservation priorities. Nature 403: 853858.

[2] Beltrán, B.J., Franklin, J., Syphard, A.D., Regan, H.M., Flint, L.E. and Flint A.L. (2014) Effects of climate change and urban development on the distribution and conservation of vegetation in a Mediterranean type ecosystem. International Journal of Geograph. Information Science, 28(8): 1561-1589.

[3] Doblas-Miranda, E., Alonso, R., Arnan, X., Bermejo, V., Brotons, L., de lasHeras, J., Estiarte, M., Hódar, J.A., Llorens, P., Lloret, F., López-Serrano, F.R., Martínez-Vilalta, J., Moya, D., Peñuelas, J., Pino, J., Rodrigo, A., Roura-Pascual, N., Valladares, F., Vilà, M., Zamora, R. and Retana, J. (2017). A review of the combination among global change factors in forests, shrublands and pastures of the Mediterranean Region: Beyond drought effects, Global and Planetary Change 148: 42-54.

[4] Regato, P. \&Korakaki, E. (2010). The Mediterranean forests against Global Climate Change. Publications: WWF Greece pp 106.

[5] Montaldo, N., Corona, R. and Albertson, J. (2016). The Climate change impact on the water balance and use efficiency of two contrasting water limited Mediterranean ecosystems in Sardinia. Geophysical Research Abstracts, Vol. 18, EGU2016-8647, EGU General Assembly 2016.

[6] Guiot, J. \& Cramer, W. (2016). Climate change: The 2015 Paris Agreement thresholds and Mediterranean basin ecosystems. Science 354(6311): 465-468.

[7] Thompson, I., Mackey, B., McNulty, S. and Mosseler, A. (2009). Forest Resilience, Biodiversity, and Climatic Change. A synthesis of the biodiversity/resilience/stability relationship in forest ecosystems. Secretariat of the Convention on Biological Diversity, Montreal. Tech. Series no. 43, pp. 67.

[8] Keenan, T., Serra, J.M., Lloret, F., Ninyerola, M. and Sabate, S. (2011). Predicting the future of forests in the Mediterranean under climate change, with nicheand process-based models: $\mathrm{CO}_{2}$ matters! Glob. Chang. Biol. 17: 565-579

[9] Giorgi, F. (2006). Climate change hot-spots. Geophys. Res. Lett. 33: L08707.

[10] IPCC (2007). Climate Change 2007: Impacts, Adaptation and Vulnerability: Contribution of Working Group II to the Fourth Assessment Report of the Intergovernmental Panel on Climate Change. Cam- 
bridge University Press, Cambridge, U.K. and New York, NY.

[11] Harrison, P.A., Berry, P.M., Simpson, G., Haslett, J.R., Blicharska, M., Bucur, M., Dunford, R., Egoh, B., Garcia-Llorente, M., Geamănă, N., Geertsema, W., Lommelen, E., Meiresonne, L. and Turkelboom, F. (2014). Linkages between biodiversity attributes and ecosystem services: A systematic review. Ecosystem Services 9: 191-203.

[12] Sahney, S., Benton, M.J. and Falcon-Lang, H.J. (2010). Rainforest collapse triggered Pennsylvanian tetrapod diversification in Euramerica. Geology 38: 1079-1082.

[13] Seufert, G., Kotzias, D., Sparta, C. and Versino, B. (1995). Volatile organics in Mediterranean shrubs and their potential role in a changing en-vironment. Global change and Mediterranean type ecosystems pp.343-370. Springer-Verlag, New York.

[14] Cook, B.I., Anchukaitis, K.J., Touchan, R., Meko, D.M. and Cook, E.R. (2016). Spatiotemporal drought variability in the Mediterranean over the last 900 years. J. Geophys. Res. Atmos. 121 (5): 2060-2074..

[15] IPCC (2014). Summary for Policymakers. In: Climate Change 2014: Mitigation of Climate Change. Contribution of Working Group III to the Fifth Assessment Report of the IPCC [Edenhofer, O., R. Pichs-Madruga, Y. Sokona, E. Farahani, S. Kadner, K. Seyboth, A. Adler, I. Baum, S. Brunner, P. Eickemeier, B. Kriemann, J. Savolainen, S. Schlömer, C. von Stechow, T. Zwickel and J.C. Minx (eds.)]. Cambridge University Press, Cambridge, United Kingdom and New York, NY, USA.

[16] Gao, X. \&Giorgi, F. (2008). Increased aridity in the Mediterranean region under greenhouse gas forcing estimated from high resolution simulations with a regional climate model. Global and Planetary Change 62: 195-209.

[17] Hoerling, M., Eischeid, J., Perlwitz, J., Quan, X., Zhang, T. and Pegion, P. (2011). On the increased frequency of Mediterranean drought. Journal of Climate 25, 2146-2161.

[18] Solomon, S., Qin, D., Manning, M., Chen, Z., Marquis, M., Averyt, K.B., Tignor, M. and Miller, H.L. (2007). Climate Change 2007: The Physical Science Basis. Working Group I Contribution to the Fourth Assessment Report of the IPCC. Cambridge University Press, Cambridge, 996 pp.

[19] Hatfield, J.L. \&Prueger, J.H. (2015). Temperature extremes: Effect on plant growth and development. Weather Clim. Extremes 10:4-10.

[20] Giorgi, F. \&Lionello, P. (2008). Climate Change Projections for the Mediterranean Region Global and Planetary Change 63:90-104.
[21] Petit, S., Firbank, L., Wyatt B. and Howard, D. (2001). MIRABEL: Models for Integrated Review and Assessment of Biodiversity in European Landscapes. A Journal of the Human Environment 30: 8188.

[22] Tinner, W., van Leeuwen, J.F.N., Colombaroli, D., Vescovi, E., van der Knaap, W.O., Henne, P., Pasta, S., D'Angelo, S. and La Mantiaf, T. (2009). Holocene environmental and climatic changes at Gorgo Basso, a coastal lake in southern Sicily, Italy. QuatSci Rev 28(15-16):1498-1510.

[23] Henne, P.D., Elkin, C., Colombaroli, D., Samartin, S., Bugmann, H., Heiri, O. and Tinner, W. (2013). Impacts of changing climate and land use on vegetation dynamics in a Mediterranean ecosystem: insights from paleoecology and dynamic modeling. Landscape Ecol. 28: 819-833.

[24] Sala, O.E., Chapin III, F.S., Armesto, J.J., Berlow, E., Bloomfield, J., Dirzo, R., Huber-Sanwald, E., Huenneke, L.F., Jackson, R.B., Kinzig, A., Leemans, R., Lodge, D.M., Mooney, H.A., Oesterheld, M., Poff, N.L., Sykes, M.T., Walker, B.H., Walker, M. and Wall, D.H. (2000). Global biodiversity scenarios for the year 2100. Science, 287 (5459), 1770-1774.

[25] Christensen, J.H., Hewitson, B., Busuioc, A., Chen, A., Gao, X., Held, I., Jones, R., Kolli,R.K., Kwon, W.-T., Laprise, R., Maga na Rueda, V., Mearns, L., Menéndez, C.G.,Räisänen, J., Rinke, A., Sarr, A. and Whetton, P. (2007). Regional climate projections. In: Solomon, S., Quin, D., Manning, M., Chen, Z., Marquis, M., Averyt, K.B., Tignor, M. and Miller, H.L. (Eds.), Climate Change 2007: The Physical Science Basis. Contribution of Working Group I to the Fourth Assessment Report on IPCC. Cambridge University Press, UK and New York,USA.

[26] Bussotti, F., Ferrini, F., Pollastrini, M. and Fini, A. (2014). The challenge of Mediterranean sclerophyllous vegetation under climate change: From acclimation to adaptation. Environmental and Experimental Botany 103: 80-98.

[27] Steffen, W. \&Canadell, P. (2005). Carbon Dioxide Fertilisation and Climate Change Policy. Australian Greenhouse Office, Department of Environment and Heritage: Canberra. pp. 33.

[28] Ainsworth, E.A. \& Long, S.P. (2005). What we have learned from 15 years of free-air $\mathrm{CO}_{2}$ enrichment (FACE)? A meta-analytic review of the responses of photosynthesis, canopy properties and plant production to rising $\mathrm{CO}_{2}$. New Phytol. 165: 351-372.

[29] Asshoff, R., Zotz, G. and Korner, C. (2006). Growth and phenology of mature temperateforest trees in elevated CO. Global Change Biology 12: 848-861. 
[30] Hungate, B.A., Dukes, J.S., Shaw, M.R., Luo, Y. and Field, C.B. (2003). Nitrogen and Climate Change. Science 302: 1512-1513.

[31] Luo, Y., Su, B., Currie, W.S., Dukes, J.S., Finzi, A., Hartwig, U., Hungate, B., McMurtrie, R.E., Oren, R., Parton, W.J., Pataki, D.E., Shaw, M.R., Zak, D.R. and Field, C.B. (2004). Progressive nitrogen limitation of ecosystem responses to rising atmospheric carbon dioxide. BioScience 54: 731-739.

[32] Norby, R.J., DeLucia, E.H., Gielen, B., Calfapietra, C., Giardina, C.P., King, J.S., Ledford, J., McCarthy, H.R., Moore, D.J.P., Ceulemans, R., de Angelis, P., Finzi, A.C., Karnosky, D.F., Kubiske, M.E., Lukac, M., Pregitzer, K.S., Scarascia-Mugnozza, G.E., Schlesinger, W.H. and Oren, R. (2005). Forest response to elevated $\mathrm{CO} 2$ is conserved across a broad range of productivity. Proceedings of the National Academy of Sciences USA 102: 18052-18056.

[33] Nicault, A., Alleaume, S., Brewer, S., Carrer, M., Nola, P. and Guiot, J. (2008). Mediterranean drought fluctuation during the last 500 years based on treering data. Climate Dynamics 31: 227-245

[34] Zhao, M. \& Running, S.W. (2010). Drought-induced reduction in global terrestrial net primary production from 2000 through 2009. Science 329: 940-943.

[35] Leonardi, S., Gentilesca, T., Guerrieri, R., Ripullone, F., Magnani, F., Mencuccini, M., Noije, T.V. and Borghetti, M. (2012). Assessing the effects of nitrogen deposition and climate on carbon isotope discrimination and intrinsic water-use efficiency of angiosperm and conifer trees under rising $\mathrm{CO}_{2}$ conditions. Global Change Biology 18: 2925-2944.

[36] Sarris, D., Christodoulakis, D. and Körner, C. (2007). Recent decline in precipitation and tree growth in the eastern Mediterranean. Global Change Biology 13: 1187-1200.

[37] Vieira, J., Campelo, F. and Nabais, C. (2010). Intraannual density fluctuations of Pinuspinaster are a record of climatic changes in the western Mediterranean region. Canadian Journal of Forest Research 40: 1567-1575.

[38] Kennedy, C. (2015). 2014 State of the Climate: Carbon Dioxide. NOAA-www.climate.gov/

[39] Saxe, H., Ellsworth, D.S. and Heath, J. (1998). Tree and forest functioning in an enriched $\mathrm{CO}_{2}$ atmosphere. New Phytologist 139: 395-436.

[40] Saxe, H., Cannell, M.G.R., Johnsen, Ø., Ryan, M.G. and Vourlitis, G. (2001). Trees and forest functioning in response to global warming. New Phytologist 149: 369-400.

[41] Wertin, T.M., McGuire, M.A. and Teskey, R.O. (2011). Higher growth temperatures decreased net carbon assimilation and biomass accumulation of northern red oak seedlings near the southern limit of species range. Tree Physiology 31: 1277-1288.

[42] Fini, A., Guidi, L., Ferrini, F., Brunetti, C., Di Ferdinando, M., Biricolti, S., Pollastri, S.,Calamai, L. and Tattini, M. (2012). Drought stress has contrasting effects on antioxidant enzymes activity and phenylpropanoid biosynthesis in Fraxinusornus leaves: an excess light stress affair? Journal of Plant Physiology 169: 929-939.

[43] Scalercio, S. (2009). On top of a Mediterranean Massif: Climate change and conservation of orophilous moths at the southern boundary of their range (Lepidoptera: Macroheterocera). European Journal of Entomology 106: 231-239.

[44] Sánchez-Humanes, B. \&Espelta, J.M. (2011). Increased drought reduces acorn production in Quercus ilex coppices: thinning mitigates this effect but only in the short term. Forestry 84: 73-82.

[45] Legakis, A. \&Adamopoulou, C. (2005). Temporal responses of soil invertebrate communities to draught stress in two semiarid ecosystems of the Mediterranean. Isr. J. Zool. 51: 331-348.

[46] Valladares, F., Zaragoza-Castells, J., SánchezGómez, D., Matesanz, S., Alonso, B., Portsmuth, A., Delgado, A. and Atkin, O.K. (2008). Is shade beneficial for Mediterranean shrubs experiencing periods of extreme drought and late-winter frosts? Annals of Botany 102: 923-933

[47] Lenoir, J., Gegout, J.C., Marquet, P.A., de Ruffray, P. and Brisse, H. (2008). A significant upward shift in plant species optimum elevation during the 20th century. Science 320(5884): 1768-1771.

[48] Richebusch, S., Thuiller, W., Hickler, T., Araujo, M.B., Sykes, M.T., Schweiger, O. and Lafourcade, B. (2008). Incorporating the effects of changes in vegetation functioning and $\mathrm{CO}_{2}$ on water availability in plant habitat models. Biology Letters 4: 556- 559 .

[49] Higgins, S.I. \&Scheiter, S. (2012). Atmospheric $\mathrm{CO}_{2}$ forces abrupt vegetation shifts locally, but not globally. Nature 488: $209-212$.

[50] Skov, F. \&Svenning, J.C. (2004). Potential impact of climatic change on the distribution of forest herbs in Europe. Ecography 27: 366-380.

[51] Tinner, W. \&Lotter, A.F. (2006). Holocene expansions of Fagussilvatica and Abiesalba in Central Europe: Where are we after eight decades of debate? Quaternary Science Reviews 25: 526 - 549.

[52] Loarie, S.R., Duffy, P.B., Hamilton, H., Asner, G.P., Field, C.B. and Ackerly, D.D. (2009). The velocity of climate change. Nature 462: 1052-1055.

[53] Svenning, J.-C. \&Sandel, B. (2013). Disequilibrium vegetation dynamics under future climate change. American Journal of Botany 100(7): 1266-1286. 
[54] Clark, J.S., Lewis, M. and Horvath, L. (2001). Invasion by extremes: Population spread with variation in dispersal and reproduction. American Naturalist 157: $537-554$.

[55] Higgins S.I., Lavorel S. and Revilla E., 2003. Estimating plant migration rates under habitat loss and fragmentation. Oikos101 : 354-366.

[56] Davis, M.B., Shaw, R.G. and Etterson, J.R. (2005). Evolutionary responses to changing climate. Ecology 86: 1704-1714.

[57] Reyer, C.P.O., Leuzinger, S., Rammig, A., Wolf, A., Bartholomeus, R.P., Bonfante, A., DeLorenzi, F., Dury, M., Gloning, P., AbouJaoudé, R., Klein, T., Kuster, T.M., Martins,M., Niedrist, G., Riccardi, M., Wohlfahrt, G., De Angelis, P., De Dato, G., François, L., Menzel, A. and Pereira, M. (2013). A plant's perspective of extremes: terrestrial plant responses to changing climatic variability. Global Change Biology 19: 75-89.

[58] Ogaya, R. \&Peñuelas, J. (2003). Comparative field study of Quercus ilex and Phillyrealatifolia: photosynthetic response to experimental drought conditions. Environ. andExper. Botany 50: 137-148.

[59] Prieto, P., Peñuelas, J., Lluisà, J., Asensio, D. and Estiarte, M. (2009). Effects of long-term experimental night-time warming and drought on photosynthesis, Fv/Fm and stomatal conductance in the dominant species of the Mediterranean shrubland. ActaPhysiologiaPlantarum 31: 729-739.

[60] Ogaya, R., Peñuelas, J., Asensio, D. and Llusià, J. (2011). Chlorophyll fluorescence responses to temperature and water availability in two co-dominant Mediterranean shrub and tree species in a long-term field experiment simulating climate change. Environmental and Experimental Botany 73: 89-93.

[61] Bakkenes, M., Eickhout, B. and Alkemade, R. (2006). Impacts of different climate stabilization scenarios on plant species in Europe. Glob. Environ. Change 16: 19-28.

[62] Ruiz-Labourdette, D., Fe Schmitz, M. and Pineda, F.D. (2013). Changes in tree species composition in Mediterranean mountains under climate change: Indicators for conservation planning. Ecological Indicators 24: $310-323$.

[63] Morin, X., Roy, J., Sonié, L. and Chuine, I. (2010). Changes in leaf phenology of three European oak species in response to experimental climate change. New Phytologist 186: 900-910.

[64] Klein, T., Di Matteo, G., Rotenberg, E., Cohen, S. and Yakir, D. (2013). Differential ecophysiological response of a major Mediterranean pine species across a climatic gradient. Tree Physiology 33: 2636.
[65] Rosenzweig, C., Casassa, G., Karoly, D.J., Imeson, A., Liu, C., Menzel, A., Rawlins, S., Root, T.L., Seguin, B. and Tryjanowski, P. (2007). Assessment of observed changes and responses in natural and managed systems. In: Parry, M.L., Canziani, O.F., Palutikof, J.P., van der Linden, P.J., Hanson, C.E. (Eds.), Climate Change 2007: Impacts, Adaptation and Vulnerability. Contribution of Working Group II to the Fourth Assessment Report of the IPCC. Cambridge UP, Cambridge, UK, pp. 79-131.

[66] Peñuelas, J. \&Filella, I. (2001). Phenology: responses to a warming world. Science 294: 793-795.

[67] Parry, M.L., Canziani, O.F., Palutikof, J.P., van der Linden, P.J. and Hanson, C.E. (Eds.) (2007). Climate Change 2007: Impacts, Adaptation and Vulnerability. Contribution of Working Group II to the Fourth Assessment Report of the IPCC. Cambridge UP, Cambridge, UK, $976 \mathrm{pp}$.

[68] Gordo, O. \&Sanz, J.J. (2010). Impact of climate change on plant phenology in Mediterranean ecosystems. Global Change Biol. 16: 1082-1106.

[69] Cleland, E.E., Chiariello, N.R., Loarie, S.R., Mooney, H.A. and Field, C.B. (2006). Diverse responses of phenology to global changes in a grassland ecosystem. Proc. Natl. Acad. Sci. U. S. A. 103: 13740-21374.

[70] Richardson, A.D., Keenan, T.F., Migliavacca, M., Ryu, Y., Sonnentag, O. and Toomey, M. (2013). Climate change, phenology, and phenological control of vegetation feedbacks to the climate system. Agricultural and Forest Meteorology 169: 156- 173.

[71] Matesanz, S., Escudero, A. and Valladares, F. (2009). Impact of three global change drivers on a Mediterranean shrub. Ecology 90: 2609-2621.

[72] Peñuelas, J., Filella, I. and Comas, P. (2003). Changed plant and animal lifecycles from 1952 to 2000 in the Mediterranean region. Glob. Change Biol. 8:531-544.

[73] Ma, S., Baldocchi, D.D., Xu, L. and Hehn, T. (2007). Inter-annual variability in carbon dioxide exchange of an oak/grass savanna and open grassland in California. Agric. Forest Meteorol. 147, 157-171.

[74] Carmo, M., Moreira, F., Casimiro, P. and Vaz, P. (2011). Land use and topography influences on wildfire occurrence in northern Portugal. Landscape and Urban Planning 100: 169-176.

[75] Moriondo, M., Good, P., Durao, R., Bindi, M., Giannakopoulos, C. and Corte-Real, J. (2006). Potential impact of climate change on fire risk in the Mediterranean area. Clim. Res. 31: 85-95.

[76] Podur, J. \& Wotton, M. (2010). Will climate change overwhelm fire management capacity? Ecol. Model. 221: 1301-1309. 
[77] Lloret, F., Estevan, H., Vayreda, J. and Terradas, J. (2005). Fire regenerative syndromes of forest woody species across fire and climatic gradients. Oecologia 146: 461-468.

[78] Bendel, M., Tinner, W. and Ammann, B. (2006). Forest dynamics in the Pfyn forest in recent centuries (Valais, Switzerland, Central Alps): interaction of pine (Pinussylvestris) and oak (Quercus sp.) under changing land use and fire frequency. The Holocene 16: 81-89.

[79] Zedler, P.H. (1995). Are some plants born to burn? Trends Ecol. Evol. 10: 393-395.

[80] Valdecantos, A. (2008). Post-fire restoration strategies/interventions to increase forest resilience against large forest fires exacerbated by climate change: The case of Valencia (Spain). In: Compte-renduprésenté los de l'atelier international UICN-WWF «Adaptation au changementclimatiquedans la gestion et la conservation des forêtsméditerranéennes », Athènes.

[81] Sherman, C., Sternberg, M. and Steinberger, Y. (2012). Effects of climate change on soil respiration and carbon processing in Mediterranean and semiarid regions: An experimental approach. European Journal of Soil Biology 52: 48-58.

[82] Birkeland, P.W. (1999). Soils and geomorphology. Oxford University Press, New York, NY, USA.

[83] Miles, J. (1985). The pedogenic effects of different species and vegetation types and the implications of succession. Journal of Soil Science 36: 571-584.

[84] Kunes, P., Odgaard, B.V. and Gaillard, M.-J. (2011). Soil phosphorus as a control of productivity and openness in temperate interglacial forest ecosystems. Journal of Biogeography 38: 2150-2164 .

[85] Johnstone, J.F. \& Chapin, F.S. (2003). Nonequilibrium succession dynamics indicate continued northern migration of lodgepole pine. Global Change Biology 9: 1401-1409.

[86] Willis, K.J., Braun, M., Sümegi, P. and Töth, A. (1997). Does soil change cause vegetation change or vice versa: A temporal perspective from Hungary. Ecology 78: $740-750$.

[87] Webb, III, T., (1986). Is vegetation in equilibrium with climate? How to interpret late-Quaternary pollen data. Vegetatio 67: $75-91$. 